\title{
Application of aluminum-based coagulants for improving efficiency of flue gas desulfurization wastewater treatment in coal - fired power plant
}

\author{
Piotr Marcinowski ${ }^{1}$, Jan Bogacki ${ }^{1}$, Maciej Majewski ${ }^{1,2,}$, , Jarosław Zawadzki ${ }^{1}$, and Sridhar \\ Sivakumar ${ }^{1}$ \\ ${ }^{1}$ Warsaw University of Technology Faculty of Building Services, Hydro and Environmental \\ Engineering, Nowowiejska 20, 00-653 Warsaw, Poland \\ ${ }^{2}$ Enea Wytwarzanie sp. z.o.o, Chemical Laboratories, Kozienice Power Plant, Świerże Górne, Al. \\ Józefa Zielińskiego 1, 26-900 Kozienice, Poland
}

\begin{abstract}
Pollution released into the environment as the result of the combustion of energy fuels is a significant global threat. For instance, wastewater in coal-fired power plants is often heavily polluted by organic compounds, heavy metals and boron. Therefore, there is an urgent need for efficient flue gases and wastewater treatment. However, to be industrially implemented, the treatment processes have to be simultaneously effective and inexpensive. This research systematically studied the efficiency of inexpensive coagulation processes using aluminum-based coagulants applied to flue gas desulfurization (FGD) wastewater treatment. Additionally, the differences in the efficiency of total organic carbon (TOC) and chemical oxygen demand (COD) removal between sedimentation and coagulation processes were systematically studied. It was found that coagulation with the appropriate dose of PAX19XL coagulant achieved a satisfactory effect with significant boron removal and almost complete heavy metals removal. The polyelectrolyte use did not improve coagulation effectiveness and did not accelerate sludge sedimentation and volume decreasing. The detailed statistical analyses did not confirm the positive, pronounced effect of coagulation compared to sedimentation, although there were observed exceptions that should be considered separately. The results obtained suggest that inexpensive aluminum-based coagulants may be effective in improving the efficiency of flue gas desulfurization wastewater treatment in coal-fired power plants.
\end{abstract}

\section{Introduction}

Most of the world's energy is produced as the result of coal and petroleum combustion. In addition to carbon, the fuel used, contains a significant amount of impurities that remain in ash and slag or go into exhaust gases. These gases are treated before discharge to the environment. The purification involves removing solid particles, nitrogen oxides and sulfur oxides. Desulfurization of gases is most often carried out with a wet lime method,

\footnotetext{
* Corresponding author: maciej.majewski@enea.pl
} 
consisting of spraying the gases with a solution of lime milk or limestone [1-3]. The desulfurization product is calcium sulfate - gypsum [4,5], which is separated from the wastewater. The wastewater from flue gas desulfurisation (FGD) is characterized by high salinity, a high content of suspended solids, heavy metals and boron. The salinity can exceed even $30000 \mathrm{mg} / \mathrm{L}$ of chlorides and $2500 \mathrm{mg} / \mathrm{L}$ of sulfates (VI). The concentration of boron in the wastewater can be up to over $350 \mathrm{mg} / \mathrm{L}$. The share of organic compounds in the total pollutant load is small. Wastewater from FGD is characterized by a differentiation in terms of qualitative and quantitative composition, depending on the type of fuel used, block load and hydraulic load of the installation. Many substances found in wastewater are compounds considered to be harmful to the environment. Most of these compounds persist in the aquatic environment and are toxic to aquatic organisms. In system power plants, most common wastewater treatment method used is based on the double coagulation with iron salts, initially at $\mathrm{pH} 6.0$ and then 8.5 , and complexation of metals using TMT-15 (15\% aqueous solution of organic sulfide, trisodium 1,3,5-triazine-2,4,6-trithiolate). This technology is partially consistent with the Council Directive [6], Regulation of the Minister of the Environment [7], Regulation of the Minister of the Environment [8] and integrated and water permits obtained by the system power plant. The use of iron-based coagulants may not be sufficient to treat wastewater to the level described in the legal requirements. This problem is especially important in the case of heavy metal and boron. Therefore, there is a need to look for other wastewater treatment methods, that are efficient, inexpensive and applicable. The aim of this study was to determine the applicability and the efficiency of aluminium-based coagulants for the treatment of wet lime method FGD wastewater in a system power plant. In addition, we examined the credibility of total organic carbon (TOC) determination in a high salinity matrix using two TOC analyzers, whose operation methods differ significantly between each other as part of this work,.

\section{Results}

\subsection{Raw wastewater}

The parameters of raw wastewater are shown in Table 1. Raw wastewater is characterized by high turbidity, associated with a high content of easily settleable solids (ESS), in the which composition predominates gypsum. Inorganic contaminants dominate in the wastewater, both in the dissolved form and in suspension. Wastewater is characterized by high salinity (Table 1: content of chlorides $8595 \mathrm{mg} / \mathrm{L}$, sulphates $1920 \mathrm{mg} / \mathrm{L}$, conductivity $33.4 \mathrm{mS} / \mathrm{cm}$ ). Significant amounts of metals were determined. The concentration of $\mathrm{Ni}, \mathrm{Pb}$ and $\mathrm{Zn}$ in raw wastewater exceeds $1 \mathrm{mg} / \mathrm{L}$, and $\mathrm{Fe}$ is in excess of $100 \mathrm{mg} / \mathrm{L}$ (Table 1). B concentration was assessed as $340 \mathrm{mg} / \mathrm{L}$, whose source is combusted coal. The FGD wastewater from the system power plant has similar parameters to that described in the available literature $[2,4,5]$.

\subsection{Sedimentation}

The results of coagulation and sedimentation are shown in Tables 2 and 3.Due to the large amount of ESS, sedimentation was very effective in FGD wastewater treatment. The use of the sedimentation alone, without the addition of coagulants, effectively removed suspensions (gypsum) and color. In addition, sedimentation decreased chemical oxygen demand (COD) from $395 \mathrm{mg} / \mathrm{L}$ to $257 \mathrm{mg} / \mathrm{L}(34.9 \%$ COD removal) and TOC from $47.73 \mathrm{mg} / \mathrm{L} / 47.95 \mathrm{mg} / \mathrm{L}$ to $44.42 \mathrm{mg} / \mathrm{L} / 44.61 \mathrm{mg} / \mathrm{L}$ (6.9\% / 7.0\% TOC removal). Thus, the 
ESS was mineral in nature, and the organic compounds were found in the raw wastewater mainly in dissolved form. With the removal of the sediment, the content of boron decreased from $340 \mathrm{mg} / \mathrm{L}$ in raw wastewater to $288 \mathrm{mg} / \mathrm{L}$ in sedimented wastewater $(15.3 \%$ removal $)$. The use of sedimentation allowed to effectively decrease the content of $\mathrm{Cr}, \mathrm{Cu}, \mathrm{Pb}$ and $\mathrm{Fe}$ by at least $97.3 \%$ (Table 1). However, in the case of $\mathrm{Ag}, \mathrm{Cd}, \mathrm{Zn}$ and $\mathrm{Ni}$, the content of these metals was reduced by $7.7 \%, 9.1 \%, 37.2 \%$ and $67.6 \%$, respectively.

\subsection{Coagulation}

The use of the coagulation process decreased the COD values from $395 \mathrm{mg} / \mathrm{L}$ to 244 $282 \mathrm{mg} / \mathrm{L}(28.6-38.2 \%$ removal) and TOC from $47.73 \mathrm{mg} / \mathrm{L} / 47.95 \mathrm{mg} / \mathrm{L}$ to $35.82-40.02$ / 37.3 - $42.1 \mathrm{mg} / \mathrm{L}(16.2$ - $25.0 / 12.2$ - 22.2\% removal).The largest COD removal was obtained using $\mathrm{Al}_{2}\left(\mathrm{SO}_{4}\right)_{3}$ at a $0.15 \mathrm{~mL} / \mathrm{L}$ dose and a pre-hydrolyzed coagulant PAX19XL at a $0.45 \mathrm{~mL} / \mathrm{L}$ dose. The COD value after the coagulation process was very similar to the raw wastewater after sedimentation. On the basis of COD values, it could be concluded, that it is impossible to choose the best type of coagulant or determine its optimal dose in terms of COD removal. The addition of polyelectrolyte does not improve the effectiveness of the coagulation process. But on the other hand, it could be concluded, that a minimal coagulant dose always ensures that the treatment process takes place.

Table 1. Parameters determined in raw wastewater

\begin{tabular}{|c|c|c|c|c|}
\hline Parameter & Unit & Value & $\begin{array}{l}\text { Legal requirement } \\
\text { the integrated permit }\end{array}$ & Determination method \\
\hline $\mathrm{pH}$ & - & 6.74 & - & PN-EN ISO 10523:2012 \\
\hline Conductivity & $\mathrm{mS} / \mathrm{cm}$ & 33.4 & - & PN-EN 27888:1999 \\
\hline COD & $\mathrm{mg} / \mathrm{L}$ & 395 & - & DIN 38409-41:1980-12 \\
\hline TOC (Shim-Pol) & $\mathrm{mg} / \mathrm{L}$ & 47.73 & - & EN 1484:1999 \\
\hline TOC (API) & $\mathrm{mg} / \mathrm{L}$ & 47.95 & - & EN 1484:1999 \\
\hline $\mathrm{F}^{-}$ & $\mathrm{mg} / \mathrm{L}$ & 13 & 25 & PN-EN ISO 10304-1:2009 \\
\hline $\mathrm{Cl}^{-}$ & $\mathrm{mg} / \mathrm{L}$ & 8595 & 19000 & PN-EN ISO 10304-1:2009 \\
\hline $\mathrm{SO}_{4}{ }^{2-}$ & $\mathrm{mg} / \mathrm{L}$ & 1920 & 2900 & PN-EN ISO 10304-1:2009 \\
\hline $\mathrm{SO}_{3}{ }^{2-}$ & $\mathrm{mg} / \mathrm{L}$ & 3.46 & - & EN ISO 10304-3:2001 \\
\hline $\mathrm{NO}_{3}^{-}$ & $\mathrm{mg} / \mathrm{L}$ & 232 & - & PN-EN ISO 10304-1:2009 \\
\hline $\mathrm{B}$ & $\mathrm{mg} / \mathrm{L}$ & 340 & 180 & PN-EN ISO 11885:2009 \\
\hline $\mathrm{Ag}$ & $\mathrm{mg} / \mathrm{L}$ & 0.039 & - & PN-EN ISO 11885:2009 \\
\hline $\mathrm{Cr}$ & $\mathrm{mg} / \mathrm{L}$ & 0.447 & - & PN-EN ISO 11885:2009 \\
\hline $\mathrm{Cu}$ & $\mathrm{mg} / \mathrm{L}$ & 0.61 & 0.5 & PN-EN ISO 11885:2009 \\
\hline $\mathrm{Ni}$ & $\mathrm{mg} / \mathrm{L}$ & 1.226 & 0.5 & PN-EN ISO 11885:2009 \\
\hline $\mathrm{Pb}$ & $\mathrm{mg} / \mathrm{L}$ & 2.018 & 0.5 & PN-EN ISO 11885:2009 \\
\hline $\mathrm{Cd}$ & $\mathrm{mg} / \mathrm{L}$ & 0.308 & 0.4 & PN-EN ISO 11885:2009 \\
\hline $\mathrm{V}$ & $\mathrm{mg} / \mathrm{L}$ & 1.489 & - & PN-EN ISO 11885:2009 \\
\hline $\mathrm{Zn}$ & $\mathrm{mg} / \mathrm{L}$ & 15.9 & 2.0 & PN-EN ISO 11885:2009 \\
\hline $\mathrm{Fe}$ & $\mathrm{mg} / \mathrm{L}$ & 129.6 & - & PN-EN ISO 11885:2009 \\
\hline
\end{tabular}


Coagulation with aluminium salts allows for the removal of dissolved organic compounds. The most effective organic compounds removal was obtained using coagulants from aqueous solutions of polyaluminium chloride, while the weakest treatment effect was using $\mathrm{Al}_{2}\left(\mathrm{SO}_{4}\right)_{3}$. The dose of the coagulant used did not have a significant impact on the efficiency of the process in the studied range.

The change in the pollutants' dispersion degree and the adsorption on the produced flocs, allowed the removal of organic compounds. Comparing the TOC values in treated wastewater, it was found that the use of coagulation allows for more than three-way more effective removal of organic pollutants in comparison to the sedimentation. The addition of flocculent in the coagulation process does not significantly affect the removal of organic compounds.

Usage of polyaluminium chloride coagulant modified by adding $\mathrm{SiO} 2$ and $\mathrm{Na}+$ and $\mathrm{Ca} 2+$ ions, the did not improve the efficiency of the process. The lack of an additional effect can be explained by the high ionic strength of the solution and the fact that ESS may act as natural ballast for the sludge formed in the coagulation process. The metals in the suspended fraction are effectively removed in the form of a separated precipitate. The use of aluminium coagulants, regardless of the type or dose, allows the removal of most heavy metals from wastewater.

Table 2. Wastewater parameters after coagulation and sedimentation

\begin{tabular}{|c|c|c|c|c|c|c|c|c|c|c|c|}
\hline Coagulant & $\left.\begin{array}{c}\text { Dose } \\
{[\mathrm{mL} / \mathrm{L}]}\end{array}\right]$ & \begin{tabular}{|c|} 
AM91 \\
3SH[m \\
g/L] \\
\end{tabular} & $\begin{array}{c}\text { COD } \\
{[\mathrm{mg} /} \\
\mathrm{L}] \\
\end{array}$ & \begin{tabular}{|c|} 
TOC \\
Shim-Pol \\
{$[\mathrm{mg} / \mathrm{L}]$} \\
\end{tabular} & \begin{tabular}{|c|} 
TOC \\
API \\
{$[\mathrm{mg} / \mathrm{L}]$}
\end{tabular} & $\begin{array}{c}\text { Conducti } \\
\text { vity } \\
{[\mathrm{mS} / \mathrm{cm}]}\end{array}$ & $\begin{array}{c}\mathrm{SO}_{3}{ }^{2-} \\
{[\mathrm{mg} / \mathrm{L}]}\end{array}$ & $\begin{array}{c}\mathrm{SO}_{4}{ }^{2-} \\
{[\mathrm{mg} / \mathrm{L}]}\end{array}$ & $\begin{array}{c}\mathrm{Cl}^{-} \\
{[\mathrm{mg} / \mathrm{L}]}\end{array}$ & $\begin{array}{c}\mathbf{F}^{-} \\
{[\mathrm{mg} / \mathbf{L}]}\end{array}$ & $\begin{array}{c}\mathrm{NO}_{3}^{-} \\
{[\mathrm{mg} / \mathrm{L}]}\end{array}$ \\
\hline $\begin{array}{l}\text { Sedimentati } \\
\text { on only }\end{array}$ & - & - & 257 & 44.42 & 44.61 & 25.2 & 5.53 & 1916 & 8886 & 11 & 175 \\
\hline Al1019 & 0.3 & - & 263 & 37.27 & 37.3 & 25.9 & 1.71 & 1969 & 9017 & 11 & 200 \\
\hline Al1019 & 0.6 & - & 255 & 38.2 & 39.6 & 25.9 & 1.95 & 1948 & 8962 & 10 & 199 \\
\hline $\mathrm{Al}_{2}\left(\mathrm{SO}_{4}\right)_{3}$ & 0.075 & - & 252 & 39.83 & 41.9 & 25.3 & 3.78 & 1945 & 8740 & 12 & 174 \\
\hline $\mathrm{Al}_{2}\left(\mathrm{SO}_{4}\right)_{3}$ & 0.15 & - & 244 & 39.81 & 41.8 & 25.4 & 3.75 & 1908 & 8756 & 12 & 173 \\
\hline $\mathrm{Al}_{2}\left(\mathrm{SO}_{4}\right)_{3}$ & 0.3 & - & 253 & 39.54 & 42.1 & 25.0 & 3.64 & 1919 & 8603 & 12 & 172 \\
\hline $\mathrm{Al}_{2}\left(\mathrm{SO}_{4}\right)_{3}$ & 0.45 & - & 256 & 39.96 & 42 & 25.1 & 3.99 & 1911 & 8594 & 14 & 171 \\
\hline $\mathrm{Al}_{2}\left(\mathrm{SO}_{4}\right)_{3}$ & 0.6 & - & 250 & 40.02 & 41.1 & 25.1 & 3.59 & 1900 & 8596 & 11 & 188 \\
\hline $\mathrm{Al}_{2}\left(\mathrm{SO}_{4}\right)_{3}$ & 0.75 & - & 258 & 39.18 & 41.1 & 26.8 & 6.51 & 1890 & 9336 & 8 & 182 \\
\hline PAX19XL & 0.075 & - & 254 & 38.57 & 40.4 & 25.3 & 3.84 & 1901 & 8718 & 9 & 184 \\
\hline PAX19XL & 0.15 & - & 250 & 38.12 & 40 & 25.3 & 3.95 & 1909 & 8647 & 10 & 179 \\
\hline PAX19XL & 0.3 & - & 262 & 38.66 & 40.1 & 25.6 & 4.26 & 1855 & 8789 & 9 & 182 \\
\hline PAX19XL & 0.45 & - & 245 & 37.72 & 40 & 26.0 & 3.60 & 1992 & 8872 & 9 & 180 \\
\hline PAX19XL & 0.6 & - & 263 & 37.65 & 39.9 & 26.3 & 3.38 & 1944 & 8990 & 9 & 178 \\
\hline PAX19XL & 0.75 & - & 282 & 35.82 & 37.8 & 27.8 & 3.94 & 1856 & 9692 & 7 & 172 \\
\hline Al1019 & 0.075 & 6 & 261 & 37.94 & $\mathrm{X}$ & 24.9 & 3.43 & 1900 & 8436 & 10 & 153 \\
\hline Al1019 & 0.15 & 6 & 273 & 37.72 & $\mathrm{X}$ & 24.8 & 3.16 & 1893 & 8440 & 9 & 153 \\
\hline PAX19XL & 0.075 & 6 & $\mathrm{X}$ & 37.71 & $\mathrm{X}$ & 24.8 & 3.53 & 1911 & 8478 & 11 & 153 \\
\hline PAX19XL & 0.15 & 6 & 265 & 38.14 & $X$ & 24.9 & 3.85 & 1891 & 8444 & 10 & 153 \\
\hline
\end{tabular}


On the other hand, the $\mathrm{Cr}, \mathrm{Cu}$ or $\mathrm{Pb}$ concentrations were comparable to those obtained as a result of the application of sedimentation alone. The use of aluminium coagulants improved the removal of $\mathrm{Zn}, \mathrm{Cd}$ and $\mathrm{Ni}$. In the case of these metals, the coagulation was used to remove about half of its content. However, which is interesting, when coagulant was supported by polyelectrolyte, the Zn removal efficiency was deteriorated.

The use of the aluminium salts coagulation was effective in removing B from wastewater, reducing its concentration from $340 \mathrm{mg} / \mathrm{L}$ in raw wastewater to $145 \mathrm{mg} / \mathrm{L}$ after coagulation PAX19XL in a $0.75 \mathrm{~mL} / \mathrm{L}$ dose $(75.3 \%$ removal). The dissolved form of $\mathrm{B}$ dominates in raw wastewater. Only $15.2 \%$ of B is associated with the easily settleable solids (ESS). In coagulation with a modified, pre-hydrolyzed polyaluminium chloride (PAX19XL) the effectiveness of $\mathrm{B}$ removal depends on the coagulant dose. For $\mathrm{Al}_{2}\left(\mathrm{SO}_{4}\right)_{3}$, compared to prehydrolyzed coagulants, based on the dose of $\mathrm{Al}^{3+}$, a worse process effect was obtained. In addition, it is not possible to determine the relationship between the effectiveness of removing $\mathrm{B}$ from wastewater and the dose of $\mathrm{Al}_{2}\left(\mathrm{SO}_{4}\right)_{3}$. Previous studies have shown, that during coagulation with iron salts at $\mathrm{pH} 6$ and 9 , B is weakly removed (maximum $25.0 \%$ removal) from this type of wastewater [9].

Table 3. Heavy metals and boron in wastewater after coagulation process

\begin{tabular}{|c|c|c|c|c|c|c|c|c|c|c|c|c|}
\hline Coagulant & $\begin{array}{c}\text { Dose } \\
{[\mathrm{mL} /} \\
\mathrm{L}]\end{array}$ & $\begin{array}{c}\text { AM913 } \\
\text { SH } \\
{[\mathrm{mg} / \mathrm{L}]}\end{array}$ & $\underset{[\mathrm{mg} / \mathrm{L}]}{\mathrm{Ag}}$ & $\begin{array}{c}\text { B } \\
{[\mathrm{mg} / \mathbf{L}} \\
]\end{array}$ & $\begin{array}{c}\mathrm{Cd} \\
{[\mathrm{mg} / \mathrm{L}]}\end{array}$ & $\begin{array}{c}\mathrm{Cu} \\
{[\mathrm{mg} / \mathrm{L}]}\end{array}$ & $\mid \begin{array}{c}\mathrm{Cr} \\
{[\mathrm{mg} / \mathrm{L}]}\end{array}$ & $\begin{array}{c}\mathbf{N i} \\
{[\mathrm{mg} / \mathrm{L}]}\end{array}$ & $\begin{array}{c}\mathbf{P b} \\
{[\mathrm{mg} / \mathrm{L}]}\end{array}$ & \begin{tabular}{|c|}
$\mathbf{V}$ \\
{$[\mathrm{mg} / \mathrm{L}$} \\
]
\end{tabular} & $\underset{[\mathrm{mg} / \mathrm{L}]}{\mathrm{Zn}}$ & $\begin{array}{c}\mathbf{F e} \\
{[\mathrm{mg} / \mathrm{L}]}\end{array}$ \\
\hline $\begin{array}{c}\text { Sedimentatio } \\
\text { n only }\end{array}$ & & & 0.036 & 288 & 0.280 & $<0.005$ & 0.012 & 0.397 & $<0.010$ & $\mathrm{x}$ & 9.99 & 0.092 \\
\hline Al1019 & 0.3 & - & $\mathrm{x}$ & 287 & 0.268 & $<0.005$ & 0.012 & 0.396 & 0.015 & 0.016 & 5.37 & 0.210 \\
\hline Al1019 & 0.6 & - & 0.025 & 282 & 0.269 & $<0.005$ & 0.015 & 0.396 & 0.011 & 0.015 & $\mathrm{x}$ & 0.146 \\
\hline $\mathrm{Al}_{2}\left(\mathrm{SO}_{4}\right)_{3}$ & 0.075 & - & 0.024 & 233 & 0.264 & $<0.005$ & 0.013 & 0.358 & $<0.010$ & $<0.005$ & 9.73 & 0.331 \\
\hline $\mathrm{Al}_{2}\left(\mathrm{SO}_{4}\right)_{3}$ & 0.15 & - & 0.024 & 217 & 0.255 & $<0.005$ & 0.015 & 0.351 & $<0.010$ & $\mid<0.005$ & 8.10 & 0.306 \\
\hline $\mathrm{Al}_{2}\left(\mathrm{SO}_{4}\right)_{3}$ & 0.3 & - & 0.128 & 248 & 0.281 & $<0.005$ & 0.018 & 0.384 & $<0.010$ & 0.008 & 5.12 & 0.376 \\
\hline $\mathrm{Al}_{2}\left(\mathrm{SO}_{4}\right)_{3}$ & 0.45 & - & 0.023 & 245 & 0.276 & $<0.005$ & 0.015 & 0.382 & $<0.010$ & 0.009 & $\mathrm{x}$ & 0.863 \\
\hline $\mathrm{Al}_{2}\left(\mathrm{SO}_{4}\right)_{3}$ & 0.6 & - & 0.024 & 274 & $\mathrm{x}$ & $<0.005$ & 0.018 & $\mathrm{x}$ & 0.014 & 0.007 & $\mathrm{x}$ & $\mathrm{x}$ \\
\hline $\mathrm{Al}_{2}\left(\mathrm{SO}_{4}\right)_{3}$ & 0.75 & - & 0.025 & 199 & 0.199 & $<0.005$ & 0.014 & $\mathrm{x}$ & $<0.010$ & $<0.005$ & 5.134 & 0.051 \\
\hline PAX19XL & 0.075 & - & 0.025 & 274 & $\mathrm{x}$ & $<0.005$ & 0.014 & $\mathrm{x}$ & $<0.010$ & $<0.005$ & $\mathrm{x}$ & 0.167 \\
\hline PAX19XL & 0.15 & - & 0.024 & 275 & $\mathrm{x}$ & $<0.005$ & 0.015 & $\mathrm{x}$ & $<0.010$ & $<0.005$ & $\mathrm{x}$ & 0.138 \\
\hline PAX19XL & 0.3 & - & 0.028 & 269 & $\mathrm{x}$ & $<0.005$ & 0.014 & $\mathrm{x}$ & $<0.010$ & $<0.005$ & $\mathrm{x}$ & 0.262 \\
\hline PAX19XL & 0.45 & - & 0.026 & 224 & $\mathrm{x}$ & $<0.005$ & 0.014 & $\mathrm{x}$ & $<0.010$ & $<0.005$ & $\mathrm{x}$ & 0.073 \\
\hline PAX19XL & 0.6 & - & 0.029 & 198 & 0.191 & $<0.005$ & 0.013 & 0.311 & $<0.010$ & $\mid<0.005$ & $\mathrm{x}$ & 0.063 \\
\hline PAX19XL & 0.75 & - & 0.033 & 145 & 0.164 & $<0.005$ & 0.009 & 0.230 & $<0.010$ & $<0.005$ & 5.800 & 0.013 \\
\hline Al1019 & 0.075 & 6 & 0.028 & 275 & 0.282 & $<0.005$ & 0.012 & 0.397 & $<0.010$ & 0.013 & 8.671 & 0.249 \\
\hline Al1019 & 0.15 & 6 & 0.028 & 277 & 0.281 & $<0.005$ & 0.014 & 0.406 & $<0.010$ & 0.008 & 7.927 & 0.845 \\
\hline PAX19XL & 0.075 & 6 & 0.029 & 281 & 0.285 & $<0.005$ & 0.013 & 0.399 & $<0.010$ & 0.014 & 8.754 & 0.311 \\
\hline PAX19XL & 0.15 & 6 & 0.027 & 281 & 0.286 & $<0.005$ & 0.013 & 0.404 & $<0.010$ & 0.012 & 8.244 & 0.258 \\
\hline
\end{tabular}

Research on coagulation with aluminium and iron salts was carried out on similar FGD wastewater samples. It can be assumed that the positive effect of B removal is related only to the change in the form in which contamination occurs, depending on the $\mathrm{pH}$, and 
sorption properties of the resulting agglomerates using different coagulates. The resulting post-coagulation sludge was characterized by a low ability for sedimentation, the lowest in the case of $\mathrm{Al}_{2}\left(\mathrm{SO}_{4}\right)_{3}$. Only as a result of the use of polyelectrolyte, the resulting sludge was easier to sediment, but still the sedimentation rate was low. Regarding the practical application of aluminum coagulants for FGD wastewater treatment, an alternative method post-coagulation sludge removal, eg. filtration, should be considered. In the case of aluminum coagulants, the pollutants' (dissolved organic compounds, boron) adsorption process is usually important in the total removal effect. Shortening the contact time with the generated sludge affects the parameters of treated wastewater, which means that the share of the adsorption process in FGD wastewater treatment may be high. This finding confirms the comparison of the effectiveness of heavy metals and B removal in sedimentation and coagulation. Similar values of TOC and COD in both processes suggests that in coagulation, the dominant treatment process is the mechanical removal of pollutants as a result of gravitational sedimentation of the formed sludge.

\section{Statistical analysis}

In order to compare the values of the TOC parameter determined with the use of two analyzers: Shimadzu and GE, a non-parametric, independent of the statistical distribution, one-sided U Mann-Withney test was performed. A pair of measurements were performed to check if the values could be considered as equivalent. The test showed that there is a statistical difference between the measurement results (the significance level $p=0.002$ ). The TOC measurements with the GE instrument were usually higher by $1.66 \mathrm{mg} / \mathrm{L}$ (the average of 14 measurement differences) than the TOC measurements made with the Shimadzu instrument. The ratios of the average difference in measurement between the TOC Shimadzu and TOC GE to the averages of measurements obtained using these analyzers were 4.3 and $4.1 \%$, respectively. The standard deviation of TOC Shimadzu and TOC GE differences was $0.73 \mathrm{mg} / \mathrm{L}$, and the ratios of this deviation to the averages of TOC Shimadzu and TOC GE measurements were 1.9 and $1.8 \%$, respectively. To compare the effect of the use of coagulation on the removal of COD with that of sedimentation, as well as with the joint use of coagulation and sedimentation, a non-parametric one-sided Wilcoxon test for one sample was performed. This test did not show a significant statistical difference between the COD values obtained after sedimentation and after coagulation. Similar results were obtained by the parametric one-sided Student's $t$ test for one sample (significance levels were $\mathrm{p}=0.90$ and $\mathrm{p}=0.68$, respectively). The average COD value from all measurements for the process of combining coagulation and sedimentation was $258 \mathrm{mg} / \mathrm{L}$, and thus it was very close to the value of $257 \mathrm{mg} / \mathrm{L}$ obtained for sedimentation alone. The standard deviation of COD differences in the two conditions of treatment process calculated for 17 different combinations of coagulants and doses were small and amounted to $9.7 \mathrm{mg} / \mathrm{L}$. The statistical analysis did not confirm the positive, pronounced effect of coagulation compared to sedimentation, although there may be exceptions that should be considered separately.

\section{Conclusion}

The use of a coagulation using aluminium coagulants and the use of flocculants allows to achieve a satisfactory effect of FGD wastewater treatment, especially in case of heavy metal removal, up to complete removal of $\mathrm{Pb}, \mathrm{Cu}, \mathrm{V}, \mathrm{Cr}$ and $\mathrm{Fe}$. The sludge generated as a result of the process are characterized by low sedimentation ability. In the case of the possible implementation of aluminium coagulants in a real installation, a more efficient 
post-coagulation sludge separation method, eg. filtration, should be applied. The use of polyelectrolyte did not increase the efficiency of COD and TOC, in the removal of heavy metal content in treated wastewater, as well as ion content. Based on the statistical analysis, it was found that there are no significant differences in the effectiveness of COD removal between the coagulation and sedimentation processes. In addition, it was confirmed that the results of determination of TOC with the use of both tested analyzers: Shimadzu TOC-L with ASI-L autosampler and GE Sievers Innovox with GE autosampler, were comparable and can be successfully used to evaluate the effectiveness of wastewater treatment processes in a system power plant. It should be emphasized that both devices were dedicated to determination of TOC in matrices with high salinity and high content of halides: structure resistant to corrosion and additional detector protection.

The authors would like to thank the operator of the system power plant for providing the laboratory. The authors would also like to thank Shim-Pol and API Instruments for providing TOC analyzers for testing. Place special or unusual abbreviations in parentheses after the full term for the first time it appears. Linguistic accuracy is the responsibility of the authors.

\section{References}

1. Ch. Feng, X. Gao, Y. Tang, Y. Zhang, Comparative life cycle environmental assessment of flue gas desulfurization technologies in China. J Clean Prod, 68, 81-92 (2014)

2. P. Córdoba, Status of Flue Gas Desulphurisation (FGD) systems from coal-fired power plants: Overview of the physic-chemical control processes of wet limestone FGDs. Fuel, 144, 274-286 (2015)

3. J. Zhu, S-Ch. Ye, J. Bai, Z-Y. Wu, Z-H. Liu, Y-F. Yang, A concise algorithm for calculating absorption height in spray tower for wet limestone-gypsum flue gas desulfurization. Fuel Process Technol, 129, 15-23 (2015)

4. J. Trojanowska, A. Litwinowicz, Possibility of heavy metal precipitation on various sludge treatment stages of a wet flue gas desulfurization process. Biuletyn Energetyka, 6, $27-32$ (2013)

5. A. Litwinowicz, Wet FGD installation wastewater treatment plant, Energetyka, 2, 360 $-363(2011)$

6. European Parliament and Council Directive 2010/75/EU of 24 November 2010, decision (UE) 2017/1442, 31072017.

7. Regulation of the Minister of the Environment of 18 November 2014 on the conditions to be met for the introduction of wastewater into waters or to land and on substances particularly harmful to the aquatic environment (Journal of Laws 2014, item 1800): Annex 4 (Tables I and II).

8. Regulation of the Minister of the Environment of 21 July 2016 on classification methods for body of water state and environmental quality standards for priority substances (Journal of Laws 2014, item 1187).

9. J. Bogacki, P. Marcinowski, J. Zawadzki, M. Majewski, S. Sivakumar, Oczyszczanie ścieków z instalacji odsiarczania spalin z wykorzystaniem procesu $\mathrm{Fe}^{0} / \mathrm{H}_{2} \mathrm{O}_{2}$. Przem. Chem., 96 (12), 2486 - 2490 (2017) 